BENM 2021

International Scientific and Practical Conference "Biotechnology, Ecology, Nature Management"

\title{
EFFECT OF ELECTROMAGNETIC RADIATION OF EXTREMELY LOW FREQUENCIES ON CARP DEVELOPMENT
}

\author{
D. V. Shumeiko (a)*, A. D. Markov (b), A. V. Abramchuk (c), V. N. Khorosheltseva (d) \\ *Corresponding author
}

(a) Kuban State University, Krasnodar, Russia, dima-shum-92@mail.ru

(b) Kuban State University, Krasnodar, Russia, markov-ad-123@yandex.ru

(c) Kuban State University, Krasnodar, Russia, apilab@yandex.ru

(d) Russian Federal Research Institute of Fisheries and Oceanography (FSBSI «VNIRO»), Azov-Black Sea branch of «VNIRO» («AzNIIRKH»), Rostov-on-Don, Russia; Southern Federal University, Rostov-on-Don,

Russia, vikakhorosheltseva@gmail.com

\begin{abstract}
The results of incubation of eggs and rearing of carp (Cyprinus carpio) larvae in water treated with lowfrequency electromagnetic radiation (LF EMP) are presented. For the control group, the containers were filled with settled tap water. In the experiment, we used similar water, which was pre-treated by exposure to low-frequency EMR: experimental group № $1-50 \mathrm{~Hz}$, № 2 - $100 \mathrm{~Hz}$, № 3 - $500 \mathrm{~Hz}$, № 4 - $1000 \mathrm{~Hz}$. The water treatment of one incubation module of the experimental groups was carried out fractionally in just 120 minutes per day. The total duration of the experiment was 16 days. It was found that water treatment with EMF NP 50, 100, 500, $1000 \mathrm{~Hz}$ does not affect the incubation time and survival throughout the experiment. As a result of rearing the larvae, significant differences from the control were revealed in terms of weight in the experimental groups with water treatment with EMF LF 100, 500, and $1000 \mathrm{~Hz}$. The final average weights of the larvae of the experimental groups were 4,4-19,3\% higher than the control. The work was aimed at studying the effect of LF EMF on fish-breeding biological indicators and, despite the existing positive effects of the application, research is required to clarify the fundamental, deep principles of this phenomenon and predict the consequences of such interventions.
\end{abstract}

2672-8575 @ 2022 Published by European Publisher.

Keywords: Cyprinus carpio, electromagnetic field, incubation, radiation, water treatment 


\section{Introduction}

One of the most important anthropogenic factors of our time is the electromagnetic field of technogenic sources. Currently, the number of technogenic sources generating an electromagnetic field (hereinafter - EMF) and affecting the environment is not decreasing, but only increasing. This is due to the constant development of radio communications, radar, radio navigation, television and other means of communication. Therefore, human civilization is faced with the problem of "electromagnetic pollution" of the environment.

\section{Problem Statement}

In the conditions of industrial fish farming, breeding objects, being in pools, are permanently influenced by sources of low-frequency (LF) EMF (fields generated by pumps, compressors, etc.). The biological effects of water with altered physicochemical characteristics after exposure to LF EMF on fish and the possibility of its use in fish farming have practically not been studied.

The main objects in the study of the biological effects of water with altered physicochemical characteristics were microorganisms (Baryshev et al., 2009, 2010; Lekhtlaan-Tynisson et al., 2004), plant seeds (Aksenov et al., 2007) and small mammals - mice and rats (Temuryants et al., 1992; Temuryants \& Grabovskaya, 1992).

Aquatic organisms are much less studied in this regard. As an example, we can cite experiments on the study of the regeneration of planarians of the genus Dugesia under the influence of weak and superweak magnetic fields (Novikov et al., 2002, 2007).

\section{Research Questions}

The subject of the research is the influence of low-frequency electromagnetic radiation (LF EMF) on aquaculture objects.

\section{Purpose of the Study}

The purpose of this research work is to study the effect of water exposed to low-frequency electromagnetic radiation on the main fish-biological indicators of rearing carp larvae (Cyprinus carpio).

\section{Research Methods}

The experiment was carried out in the laboratory of advanced technologies in aquaculture on the basis of the business incubator of the Kuban State University in the period from July 10, 2020 to July 26, 2020.

For the experiments, fertilized caviar of carp (Cyprinus carpio) was brought from OJSC "Specialized fish breeding plant of herbivorous fish".

The studies were carried out using several types of installations, which were located in a heatinsulated room with an area of $68 \mathrm{~m} 2$. For incubation of eggs, collection of prelarvae. isolated modules 
were developed for their keeping, rearing the larvae (Figure 1). Each module consisted of two plastic identical containers with a volume of 60,0 liters each with a Weiss-type incubator with a volume of 1,2 liters (a glass bottle with a cut-off bottom and an adapter made of PVC ventilation reduction and angle) and a water circulation system. The flow was created by an airlift. One container was a water storage tank, the second was a prelarva collection. The flow rate in the system, primarily the volume of water supply to the incubation flask, was regulated by the total volume of water (the more water, the higher the water column in the containers, the more intensively the water rose) and by the tap. The filter was a removable filter cup $30,5 \mathrm{~cm}$ high and $4 \mathrm{~cm}$ in diameter.

The incubation modules were located in two communicating rooms at a distance of at least $0,5 \mathrm{~m}$ from the walls to reduce the likelihood of exposure to EMR from the hidden electrical networks of the building. In total, 10 such independent modules were used. The airlifts of the modules were fed with air from two Hailea Electrical Magnetic AC ACO-500 reciprocating compressors.

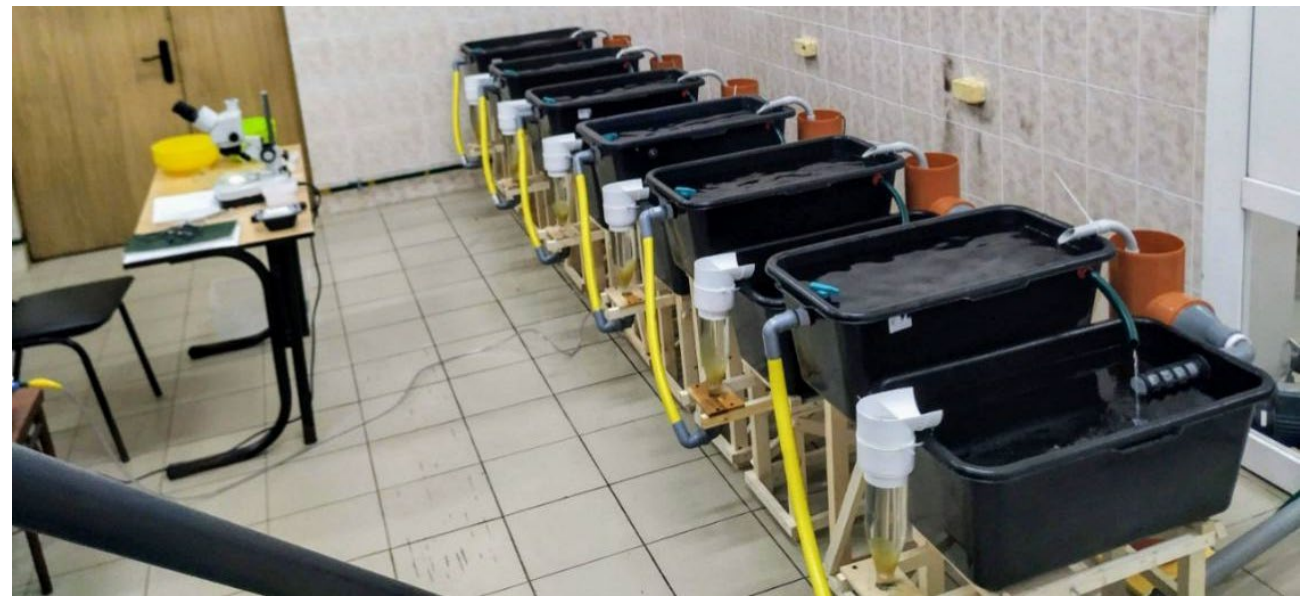

Figure 1. General view of the experimental module for incubation of eggs

For growing carp larvae in order to find out the residual effect of low-frequency EMR on objects, a RAS module was assembled. This RAS is represented by standard units: growing tanks, a coarse mechanical and biological filter, a pump for water circulation, a compressor and PVC connecting pipes. The biological filter and growth trays were made of $5 \mathrm{~mm}$ thick polypropylene sheet and mounted on racks made of wooden beams at a height of $75,0 \mathrm{~cm}$ and $50,5 \mathrm{~cm}$, respectively. Five growth trays had the following dimensions (length, width, height): $112 \times 41 \times 40 \mathrm{~cm}$.

Biological filter (length, width, height) $112 \times 50 \times 60 \mathrm{~cm}$ divided into four compartments - three (total volume $0.288 \mathrm{~m} 3$ ) with RK BioElements floating polypropylene granule with a density of $0,93 \mathrm{~g} /$ $\mathrm{cm} 3$ and a specific surface area of $750 \mathrm{~m} 2 / \mathrm{m} 3$; the fourth is a storage tank with a thermostat.

Water was supplied through a system of polypropylene pipes and fittings with a diameter ranging from $50 \mathrm{~mm}$ at the outlet from the biological filter to $40 \mathrm{~mm}$ at the supply to the trays. To remove waste water from the tray, a bottom drain was made with a removable filter cup $30,5 \mathrm{~cm}$ high and $40 \mathrm{~mm}$ in diameter, covered with a stainless steel mesh with a mesh of $0,7 \mathrm{~mm}$ and a wire thickness of $0,25 \mathrm{~mm}$. The drain was made with outlet pipes with a diameter of $50 \mathrm{~mm}$ and a main collecting pipe of $110 \mathrm{~mm}$. The water was circulated using an Astral pool Sena pump with a declared capacity of $7 \mathrm{~m} 3 / \mathrm{h}$. The water 
flow was regulated by taps, taking into account the pressure loss on the mechanical sand filter from 1,0 to $1,5 \mathrm{~m} 3 / \mathrm{h}$, since the basic pump power was excessive. For coarse mechanical cleaning, a $450 \mathrm{~mm}$ Astral pool Aster sand filter with a sand filtration area of $0,16 \mathrm{~m} 2$ was used, the filler was 3-5 mm quartz sand.

General view and layout of the experimental module for rearing larvae and juveniles is presented in Figure 2.

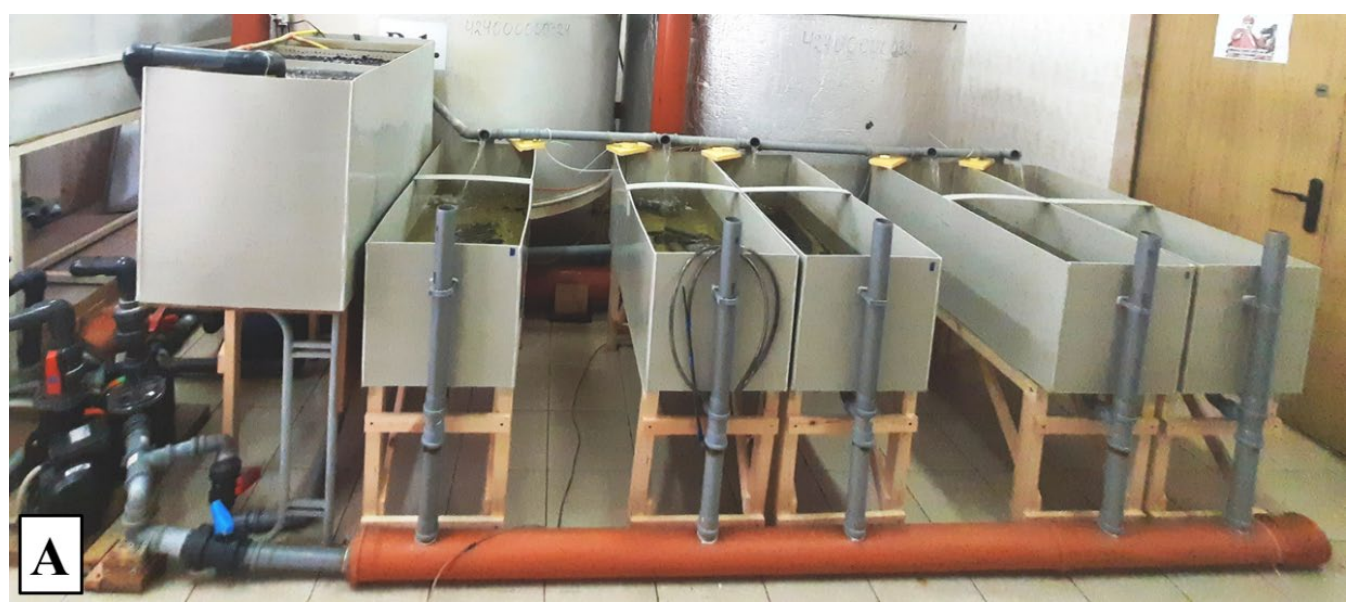

View from above
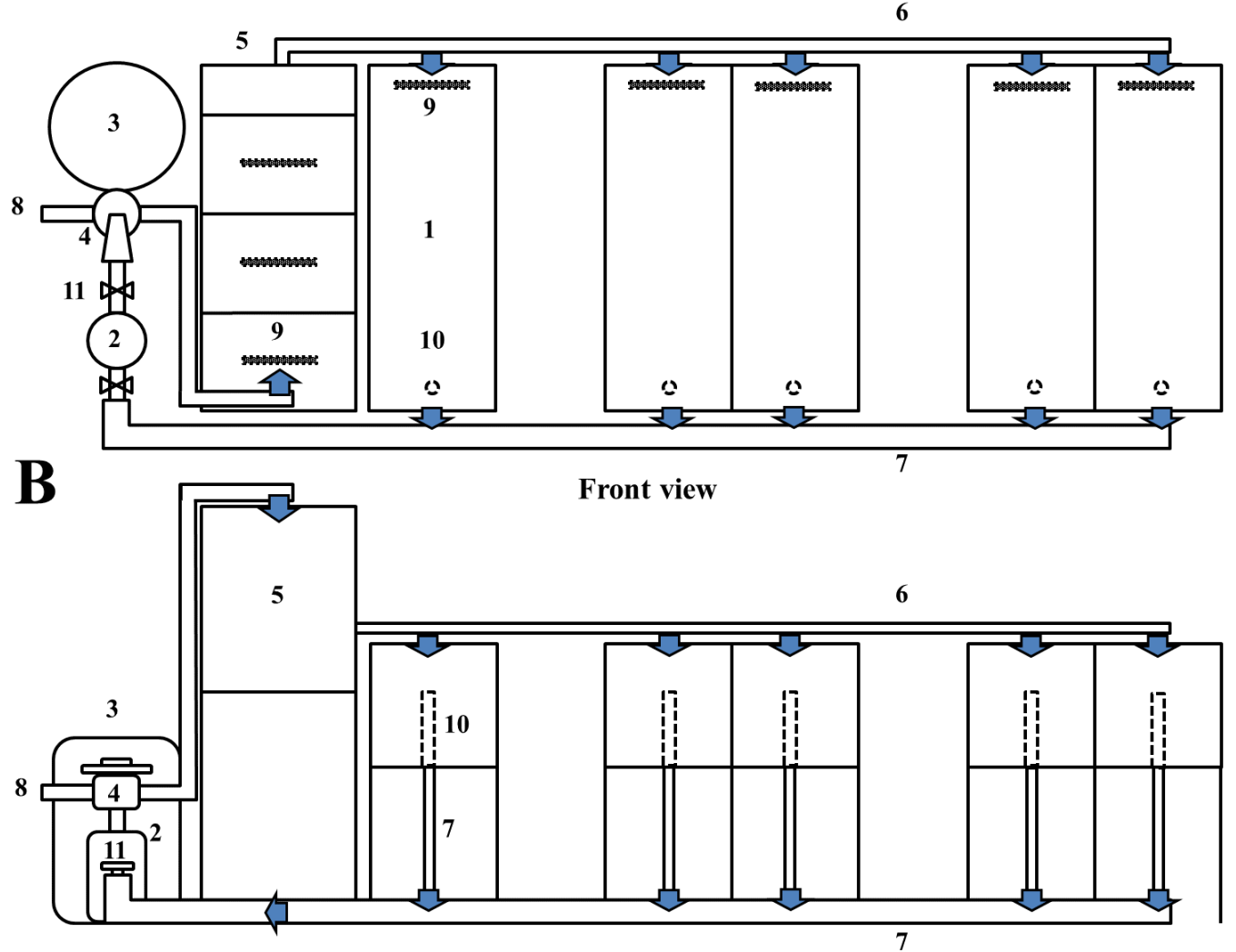

1 - growing trays; 2 - pump; 3 - mechanical filter; 4 - selector valve; 5 - biological filter; 6 - water supply pipeline; 7 - spillway pipeline; 8 - sewer drain; 9 - air diffusers; 10 - filter cup; 11 - crane

Figure 2. General view (A) and plan-diagram (B) of the experimental recirculation module for rearing larvae and juvenile carp 
For the control group, the containers were filled with settled tap water (Table 1). In the experiment, we used similar water, which was pre-treated by exposure to low-frequency EMR: experimental group № $1-50 \mathrm{~Hz}$, № 2 - $100 \mathrm{~Hz}$, № 3 - $500 \mathrm{~Hz}$, № 4 - $1000 \mathrm{~Hz}$.

Table 1. Chemical composition of tap water

\begin{tabular}{cc}
\hline Indicator & The values \\
\hline $\mathrm{pH}$ & 7,9 \\
Hardness, mg-eq / & 2,9 \\
$\mathrm{C}\left(\mathrm{Ca}^{2+}\right), \mathrm{mg}$-eq / 1 & 2,2 \\
$\mathrm{C}\left(\mathrm{Mg}^{2+}\right), \mathrm{mg}-\mathrm{eq} / 1$ & 0,7 \\
$\mathrm{C}\left(\mathrm{HCO}_{3}\right), \mathrm{mmol} / 1$ & 4,53 \\
$\mathrm{C}\left(\mathrm{H}_{2} \mathrm{CO}_{3}\right), \mathrm{mmol} / 1$ & 0,21 \\
$\mathrm{C}\left(\mathrm{Cl}^{-}\right), \mathrm{mmol} / \mathrm{l}$ & 0,8 \\
$\mathrm{C}\left(\mathrm{SO}_{4}{ }^{2-}\right), \mathrm{mmol} / \mathrm{l}$ & 0,42 \\
$\mathrm{C}\left(\mathrm{Na}^{+}\right), \mathrm{mmol} / 1$ & 5,63 \\
$\mathrm{C}\left(\mathrm{K}^{+}\right), \mathrm{mmol} / \mathrm{l}$ & 0,71 \\
\hline
\end{tabular}

To concentrate the impact on a certain experimental group, the EMR source was immersed in water to a depth of about $10-12 \mathrm{~cm}$ in front of the tap of the water storage tank (Figure 3 ).

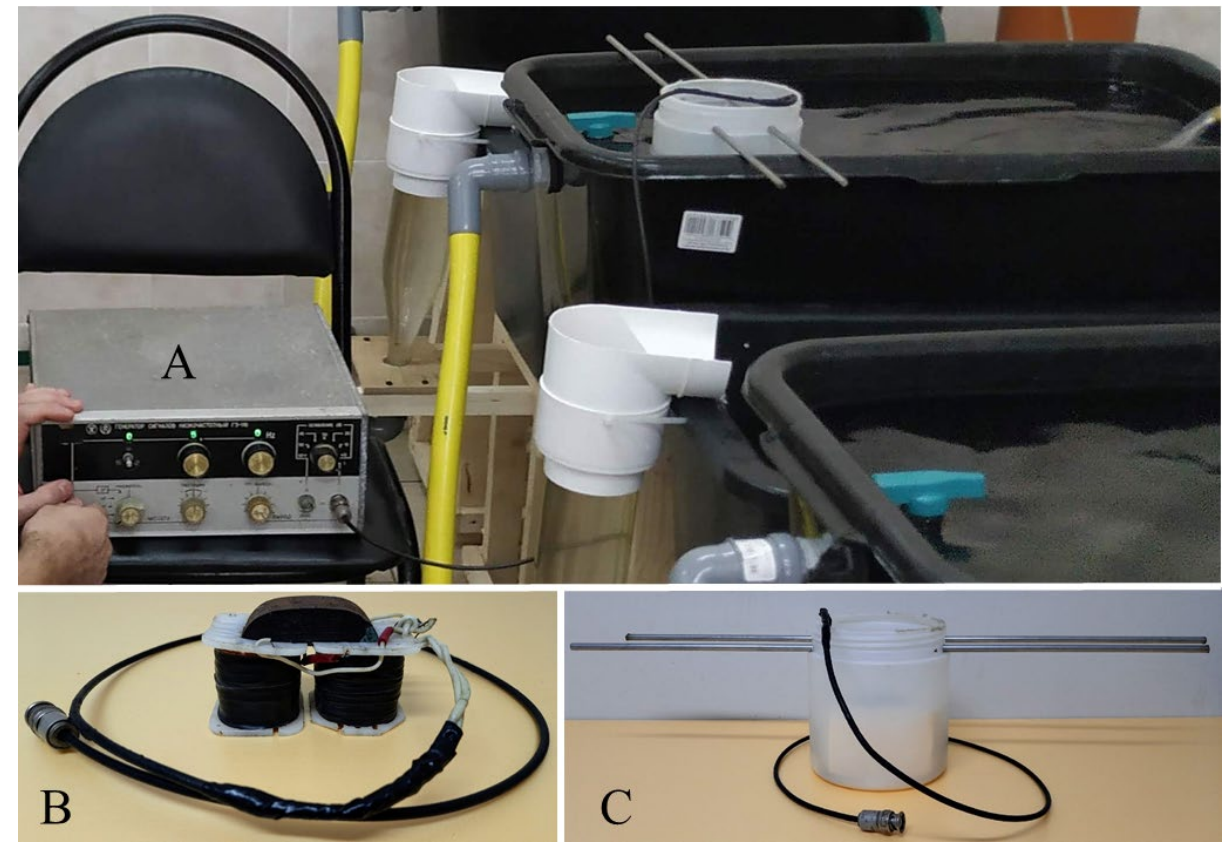

A - low-frequency signal generator G3-118; B - source of low-frequency EMP; C - container for immersing the source of low-frequency EMP into water

Figure 3. Means for treating water EMP

A multilayer coil placed on the bottom of a plastic cylindrical container (Figure 3) served as a source of low-frequency EMR. Between the treatment cycle ( 8 modules, 15 min each) for $2 \mathrm{~h}$, a break of 30 min was made and at night $3,5 \mathrm{~h}$ at $00: 30-4: 00$. 
To identify the values of the magnetic induction from the source, preliminary measurements were made outside the aquatic environment. Electromagnetic radiation around the multilayer coil is formed unevenly, therefore measurements were carried out in two areas - under the coil and on the side of it (Figure 4).

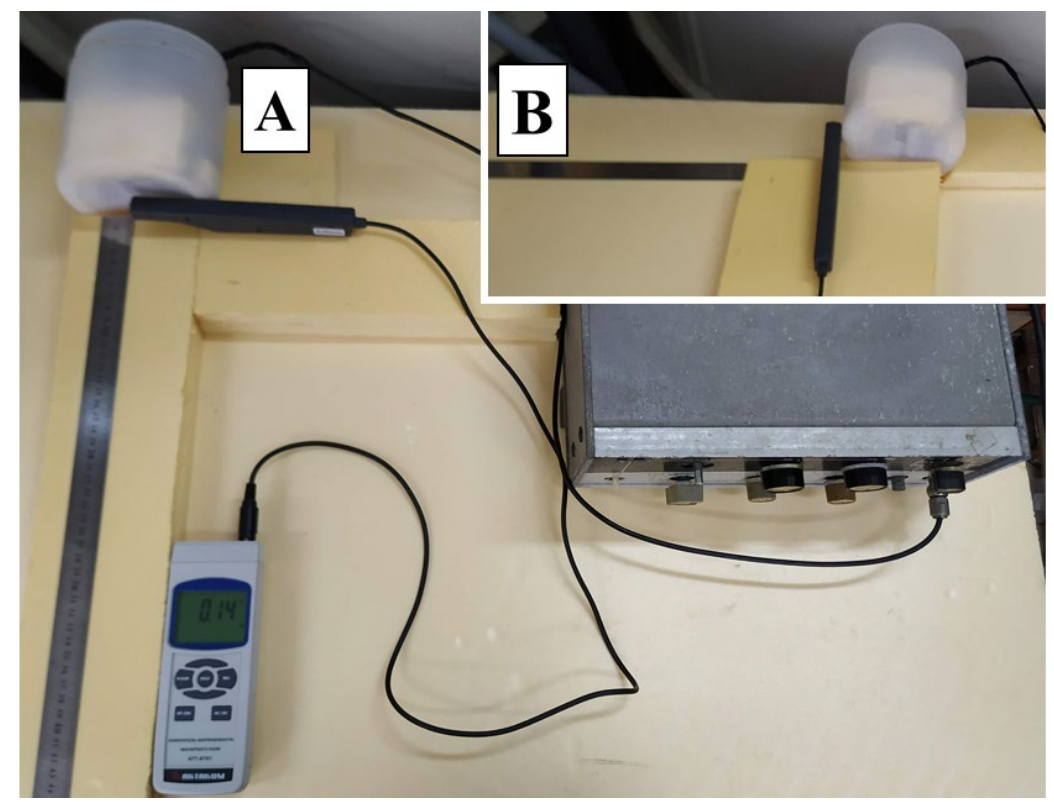

A - under the source of EMP; B - on the side of the EMR source

Figure 4. Measurement of the magnetic induction of the EMR source

The thermal and hydrochemical regimes were monitored using a Hanna HI 9146-04 oximeter, a Hanna Combo HI 98129 combined pH / EC / TDS meter, and Sera and Api colorimetric drop tests. In the process of taking into account the quality of the water used, such parameters were determined as the content of: ammonia and ammonium $\left(\mathrm{NH}_{3}, \mathrm{NH}^{+}{ }_{4}\right)$, nitrites $\left(\mathrm{NO}_{2}\right)$, the content of nitrates $\left(\mathrm{NO}_{3}\right)$, the value of the active reaction of the medium $(\mathrm{pH})$, water temperature, the content of dissolved oxygen in water $\left(\mathrm{O}_{2}\right)$.

To determine the mass indices of eggs, prelarvae and larvae, four weighed portions of 50 pieces were made, for lengths, 50 samples were taken, which were fixed with a $4 \%$ formalin solution. As a result, 500 copies were recorded and processed. for an experimental group or 5000 copies. samples for the entire experiment. The eggs and larvae were counted in a volumetric manner.

The experiment in the incubation module was carried out in duplicate, the results of each group were added. In the RAS, the experiment was performed in a single repetition. At the end of the experiment, weighed and measured the length of each individual. Eggs and larvae were weighed on torsion and electronic scales with an accuracy of 0,001 and $0,01 \mathrm{~g}$, feed - up to $0,01 \mathrm{~g}$. A binocular and an eyepiece micrometer were used to measure linear parameters.

Feeding was performed from 4 to 8 once a day between EMR water treatments with live Artemia nauplii (nauplii hatching from cysts was 85,4\%) and Coppens vital feed 0,8-1,2 $\mathrm{mm}$ with a protein content of $46,0 \%$, fat $10,0 \%$, fiber $1,0 \%$, ash $9,9 \%$ and phosphorus $1,7 \%$, which was previously ground in a coffee grinder. The daily feeding rate was selected based on the eatability and the 
recommendations of the feed manufacturers, taking into account the calculated biomass of the larvae in the containers. Artemia cysts were incubated according to the standard technique (Kovacheva et al., 2019; Voronov, 1986) in cone-shaped 1.8-liter apparatus (working volume 1,5 liters) equipped with an aeration system.

During the experiment, the main hydrochemical parameters (ammonia, nitrites, nitrates, $\mathrm{pH}$ ) were within the limits of fish breeding norms. The water temperature in the tanks was in the range of 23,4-26,5 ${ }^{\circ} \mathrm{C}$. The results were processed using standard statistical methods.

The statistical significance of differences in the groups was determined using the Mann-Whitney U-test for nonparametric and independent groups. The following indicators were calculated: mean $(\bar{x})$, standard deviation $(\sigma)$, the coefficient of variation $(\mathrm{CV})$, median, 25th $(25 \%)$ and 75 th percentile (75\%). Specific growth rate $\left(C_{w}\right)$ calculated by the formulas (Shcherbina \& Gamygin, 2006):

$$
C_{w}=\frac{\ln M_{t}-\ln M_{0}}{t} * 100 \%,
$$

$M_{0}, M_{t}$ - average mass at the beginning and end of the period. Body condition was determined by the formula:

$$
Q=\left(\frac{W}{l^{3}}\right) * 100 \%,
$$

$Q$ - body condition rate; $W$ - body weight of fish (total when calculated according to Fulton); $l$ fishing length. The calculations and graphic design of the data obtained in the work were carried out using the programs Microsoft Excel and Statistica 12.

\section{Findings}

To measure and establish the range of propagation of EMP, we used a meter of constant and alternating magnetic fields Aktakom ATT-8701. The parameters of the device are shown in Figure 5. The EMF of the source was characterized by attenuation with increasing distance from it. It should be noted that the greater the frequency of sinusoidal oscillations of the ELF range from the generator output, the lower the magnetic induction, which is associated with a constant active resistance of the coil winding and a constant current strength. The upper measurement range of the device is $300 \mu \mathrm{T}$, therefore, the EMF above this value during measurements under the source (Figure 4 A) was not recorded, as in the case of the output from the oscillator with a frequency of 50 and $100 \mathrm{~Hz}$. At 500 and $1000 \mathrm{~Hz}$, the values started from 104,9 and 59,7 $\mu \mathrm{T}$, respectively.

Measurements from the side of the coil were much smaller, with the same dependence of the magnetic induction on frequency and distance to it, and began at $50 \mathrm{~Hz}-95,3 \mu \mathrm{T}, 100 \mathrm{~Hz}-61,4 \mu \mathrm{T}, 500$ $\mathrm{Hz}-15,6 \mu \mathrm{T}, 1000 \mathrm{~Hz}-7,6 \mu \mathrm{T}$. 

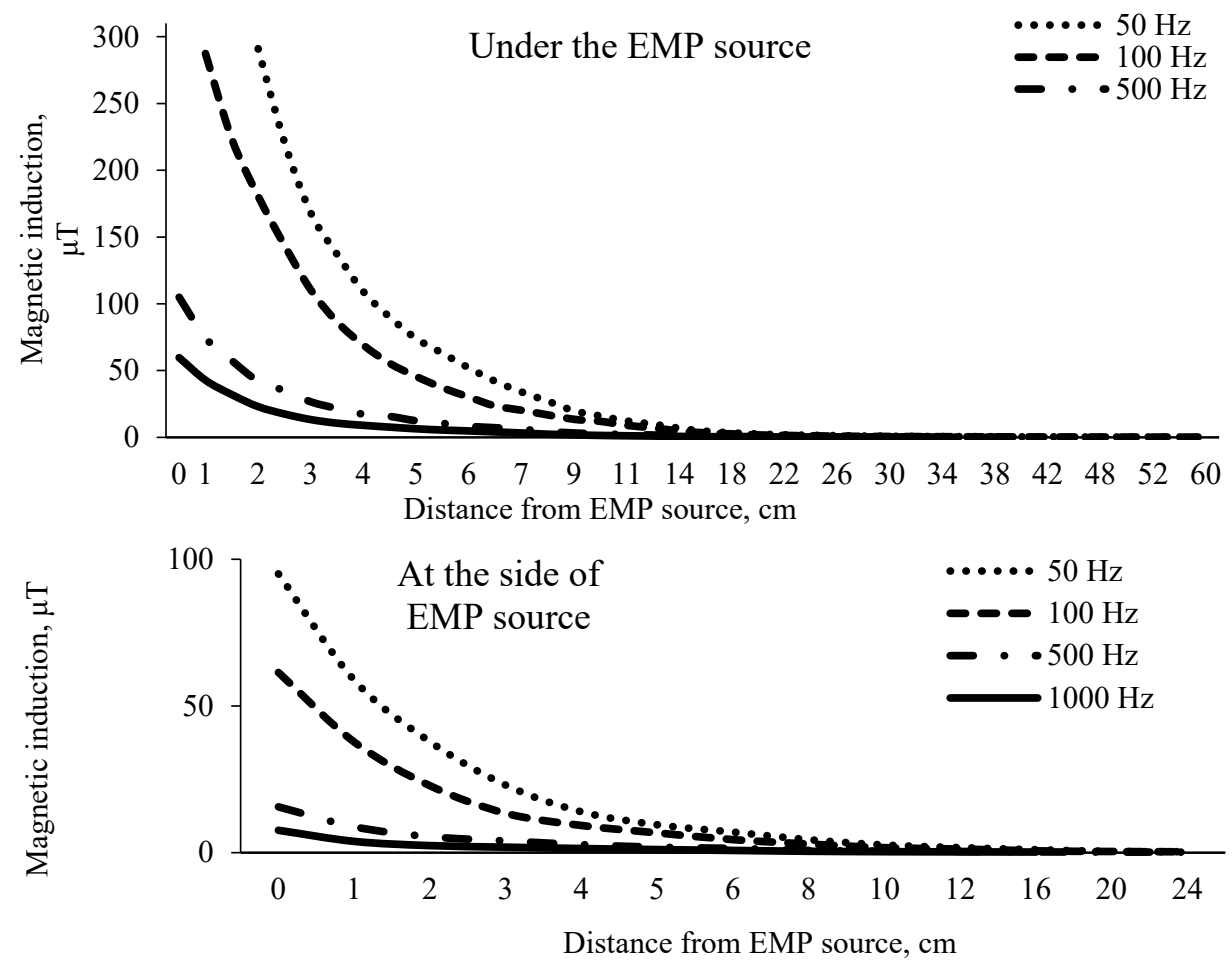

Figure 5. Magnetic induction values depending on the distance to the EMP source

The eggs were inseminated on July 10, 20 at 11:00, and were taken from the farm at 15:30. The fertilization rate of eggs was 91,2\%. Mass hatching of prelarvae in all experimental groups was recorded on July 12, 2020 at 16:00. Since eggs were obtained and incubated at late (Pashinova \& Moskul, 2014; Shchetinkina \& Rastopshina, 2020; Voroshilina et al., 2005) periods of the spawning campaign at a temperature of $23,4-24,6{ }^{\circ} \mathrm{C}$, the total incubation time of $53 \mathrm{~h}$ can be considered the norm for such conditions. The development of the embryo is shown in Figure 6.

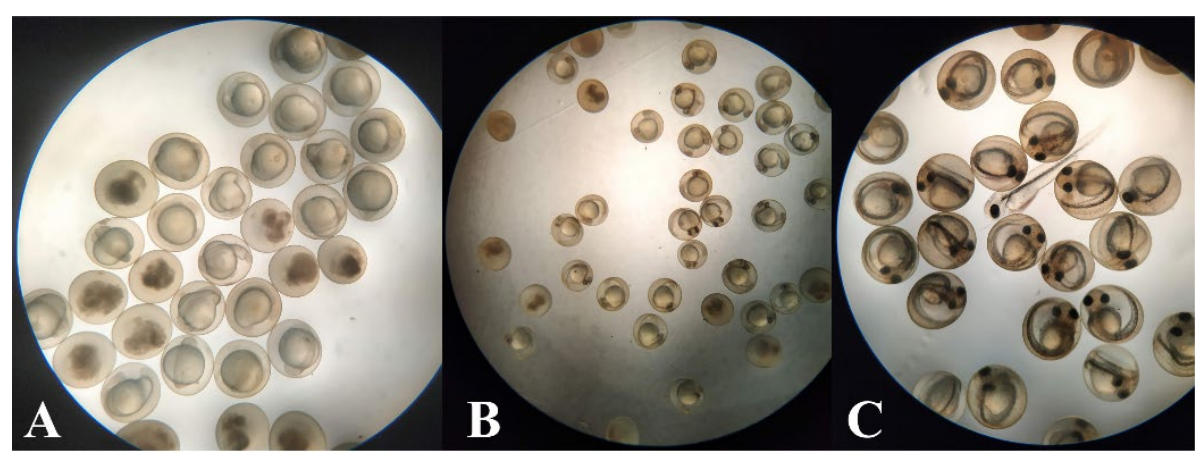

A - 18 hours; B - 33 h, C - 52 h.

Figure 6. Embryo Cyprinus carpio after fertilization of eggs

Table 2 shows the sequence of changing technological stages. Egg incubation and primary rearing were carried out in the incubation module. The estimated yield of free embryos based on fertilization 
efficiency was 91,2\% (Table 3). The survival rate of larvae during rearing in the incubation module in all groups was in the range from 84,2 to $86,1 \%$, during keeping in trays from 91,1 to $92,4 \%$. The final survival rate of the control group from the start of the incubation of eggs also did not significantly differ from the experimental groups and was more than them by a maximum of $3,72 \%$.

Table 2. Chronology of the stages of the experiment

\begin{tabular}{cc}
\hline Stage & Period \\
\hline Incubation of eggs & $10.07 .20(16: 00)-12.07 .20(16: 00)$ \\
Holding free embryos & $12.07 .20(16: 00)-14.07 .20$ \\
Growing larvae in the incubation module & $14.07 .20-20.07 .20$ \\
Growing larvae in recirculating water trays & $20.07 .20-26.07 .20$ \\
\hline
\end{tabular}

The stocking density of prelarvae and larvae, taking into account the working volume of the holding container of 45 l, ranged from 273 to $230 \mathrm{pcs} / 1$. As the larvae grew, they were transplanted into a recirculation module for 5 trays in accordance with the experimental group. The stocking density of larvae in this case on a 1371 tray was from 154 to $137 \mathrm{pcs} / 1$.

Table 3. Cyprinus carpio survival rates during the experiment

\begin{tabular}{ccccccc}
\hline \multirow{2}{*}{ Stage } & \multirow{2}{*}{ Result } & \multicolumn{5}{c}{ Experienced group } \\
& & control & № 1 & № 2 & № 3 & № 4 \\
\hline Caviar & pieces & 26920 & 26920 & 26920 & 26920 & 26920 \\
Free embryos & $\%$ & & & 91,2 & & \\
Larva after rearing in the incubation module & $\%$ & 86,1 & 85,4 & 84,2 & 85,9 & 86,1 \\
Larva after rearing in RAS trays & pieces & 19532 & 19163 & 18832 & 19233 & 19384 \\
& $\%$ & 92,4 & 91,4 & 91,1 & 91,2 & 91,7 \\
Total & $\%$ & 72,6 & 71,2 & 70,0 & 71,4 & 72,0 \\
\hline
\end{tabular}

As a result of the work carried out in the period before the transition to external power supply, no significant differences were found between the experimental groups and the control. At the time of delivery of fertilized eggs, its average weight and length were 1,87 $\mathrm{mg}$ and 1,57 $\mathrm{mm}$. During incubation, the weight in some groups slightly increased.

Table 4 shows the weight of eggs at the beginning of the experiment (07/10/20), intermediate $(07 / 12 / 20$ at $4: 10)$ and after the embryos left the shells $(07 / 12 / 20$ at 16:00). You can notice a slight increase in these values in some experimental groups. At the prelarva stage, the mass decreased in comparison with the previous stages, which is due to the absence in the measured sample of the shell and intracavitary fluid of the egg, in which the embryo was previously located.

Table 4. Indicators of weight of eggs and free embryo Cyprinus carpio

\begin{tabular}{cccccc}
\hline \multirow{2}{*}{ Date } & Control & Experience № 1 & Experience № 2 & Experience № 3 & Experience № 4 \\
\cline { 2 - 5 } & \multicolumn{5}{c}{$\frac{\bar{x} \pm \sigma, \mathrm{M} \Gamma}{C V, \%}$} \\
10.07 .20 & $\frac{1,87 \pm 0,059}{3,2}$ & $\frac{1,87 \pm 0,059}{3,2}$ & $\frac{1,87 \pm 0,059}{3,2}$ & $\frac{1,87 \pm 0,059}{3,2}$ & $\frac{1,87 \pm 0,059}{3,2}$ \\
$(16: 00)$ & $\frac{1,87 \pm 0,059}{12.07 .20}$ & $\underline{1,88 \pm 0,060}$ & $\frac{1,88 \pm 0,063}{3,4}$ & $\frac{1,90 \pm 0,055}{2,9}$ & $\frac{1,91 \pm 0,061}{3,2}$ \\
$(4: 10)$ & 3,2 & 3,2 & &
\end{tabular}




\begin{tabular}{cccccc}
$\begin{array}{c}12.07 .20 \\
(16: 00)\end{array}$ & $\frac{1,78 \pm 0,047}{2,6}$ & $\frac{1,80 \pm 0,045}{2,5}$ & $\frac{1,79 \pm 0,046}{2,6}$ & $\frac{1,80 \pm 0,062}{3,4}$ & $\frac{1,81 \pm 0,043}{2,4}$ \\
\hline
\end{tabular}

At the initial stages, the prelarvae fed only on the yolk sac and are inactive. They hung one by one, evenly attached over the entire area of the walls of the incubation flask and the collection container, which indicates a positive phototaxis (Voroshilina et al., 2005).

The diameter of the eggs at the beginning of the experiment was $1,57 \mathrm{~mm}$, after 12 hours it increased by $1,8-5,7 \%$ to $1,60-1,69 \mathrm{~mm}$ (Table 5 ). The length of the prelarvae was from 5,01 to 5,03 $\mathrm{mm}$.

Table 5. Indicators of the diameter of eggs and the length of free embryos of Cyprinus carpio

\begin{tabular}{|c|c|c|c|c|c|}
\hline Date & Control & Experience № 1 & Experience № 2 & Experience № 3 & Experience № 4 \\
\hline \\
\hline \multicolumn{6}{|c|}{$\frac{\bar{x} \pm \sigma, \mathrm{MM}}{C V, \%}$} \\
\hline \multirow{2}{*}{$10.07 .20(16: 00)$} & $\underline{1,57 \pm 0,115}$ & $\underline{1,57 \pm 0,115}$ & $\underline{1,57 \pm 0,115}$ & $\underline{1,57 \pm 0,115}$ & $\underline{1,57 \pm 0,115}$ \\
\hline & 7,3 & 7,3 & 7,3 & 7,3 & 7,3 \\
\hline 12.07 .20 & $\underline{1,63 \pm 0,103}$ & $\underline{1,63 \pm 0,100}$ & $\underline{1,63 \pm 0,103}$ & $\underline{1,64 \pm 0,100}$ & $\underline{1,66 \pm 0,098}$ \\
\hline$(4: 10)$ & 6,3 & 6,1 & 6,3 & 6,1 & 5,9 \\
\hline 12.07 .20 & $\underline{5,07 \pm 0,251}$ & $\underline{5,08 \pm 0,246}$ & $\underline{5,09 \pm 0,247}$ & $\underline{5,08 \pm 0,240}$ & $\underline{5,09 \pm 0,209}$ \\
\hline$(16: 00)$ & 5,0 & 4,8 & 4,9 & 4,7 & 4,1 \\
\hline \multicolumn{6}{|c|}{$\underline{M e, \mathrm{MM}}$} \\
\hline \multirow{2}{*}{\multicolumn{6}{|c|}{$\frac{\min -\max , \mathrm{MM}}{25 \%-75 \%}$}} \\
\hline & & & & & \\
\hline \multirow{3}{*}{10.07 .20} & $\underline{1,60}$ & $\underline{1,60}$ & $\underline{1,60}$ & $\underline{1,60}$ & $\underline{1,60}$ \\
\hline & $\underline{1,34-1,69}$ & $\underline{1,34-1,69}$ & $\underline{1,34-1,69}$ & $\underline{1,34-1,69}$ & $\underline{1,34-1,69}$ \\
\hline & $1,51-1,69$ & $1,51-1,69$ & $1,51-1,69$ & $1,51-1,69$ & $1,51-1,69$ \\
\hline \multirow{3}{*}{$\begin{array}{c}12.07 .20 \\
(4: 10)\end{array}$} & $\underline{1,65}$ & $\underline{1,69}$ & $\underline{1,60}$ & $\underline{1,65}$ & $\underline{1,69}$ \\
\hline & $\underline{1, \overline{42-1,78}}$ & $\underline{1,42-1,78}$ & $\underline{1,42-1,78}$ & $\underline{1,42-1,78}$ & $\underline{1,42-1,78}$ \\
\hline & $1,60-1,69$ & $1,60-1,69$ & $1,60-1,69$ & $1,60-1,69$ & $1,60-1,69$ \\
\hline \multirow{3}{*}{$\begin{array}{c}12.07 .20 \\
(16: 00)\end{array}$} & $\underline{5,03}$ & $\underline{5,03}$ & $\underline{5,03}$ & $\underline{5,01}$ & $\underline{5,03}$ \\
\hline & $\underline{4,63-5,61}$ & $\underline{4,63-5,52}$ & $\underline{4,63-5,52}$ & $\underline{4,63-5,52}$ & $\underline{4,72-5,43}$ \\
\hline & $\overline{4,90-5,25}$ & $4,92-5,25$ & $4,90-5,25$ & $4,90-5,16$ & $4,90-5,18$ \\
\hline
\end{tabular}

During the larval period, the eyes are strongly pigmented; pigment cells are located mainly on the head and along the back. The yolk sac is significantly reduced. The mouth becomes stiff but does not close completely yet. The swim bladder is single-chambered and filled with air. The fin fold has become wider. (Pashinova \& Moskul, 2014; Voroshilina et al., 2005). The larvae grew to stage $\mathrm{D}_{1}-\mathrm{D}_{2}$ (Voroshilina et al., 2005).

Table 6 shows the feeding scheme of carp larvae at various technological stages. During the transition of prelarvae to exogenous feeding, feeding was carried out only with live food (live nauplis of Artemia salina) 4 times / day; on the following days, the frequency of feeding was increased up to 8 times / day. with their complete replacement with artificial granulated milled feed. During the rearing period, 19,2 $\mathrm{g}$ of Artemia cysts and 55,5 $\mathrm{g}$ of compound feed were consumed for each experimental group.

Table 6. Feeding scheme for Cyprinus carpio larva Once / day

\begin{tabular}{cccccccccc}
\hline $\begin{array}{c}\text { Technologica } \\
\text { I stage }\end{array}$ & $\begin{array}{c}\text { Mixed } \\
\text { meals }\end{array}$ & \multicolumn{4}{c}{$\begin{array}{c}\text { Exogenous nutrition in the } \\
\text { incubation module }\end{array}$} & $\begin{array}{c}\text { Exogenous nutrition in recirculating } \\
\text { water trays }\end{array}$ \\
\hline $\begin{array}{c}\text { Duration, } \\
\text { days }\end{array}$ & 1 & 1 & 1 & 1 & 1 & 1 & 1 & 6 \\
$\begin{array}{c}\text { Artemia } \\
\text { nauplii }\end{array}$ & 4 & 8 & 6 & 5 & 4 & 3 & 2 & -
\end{tabular}




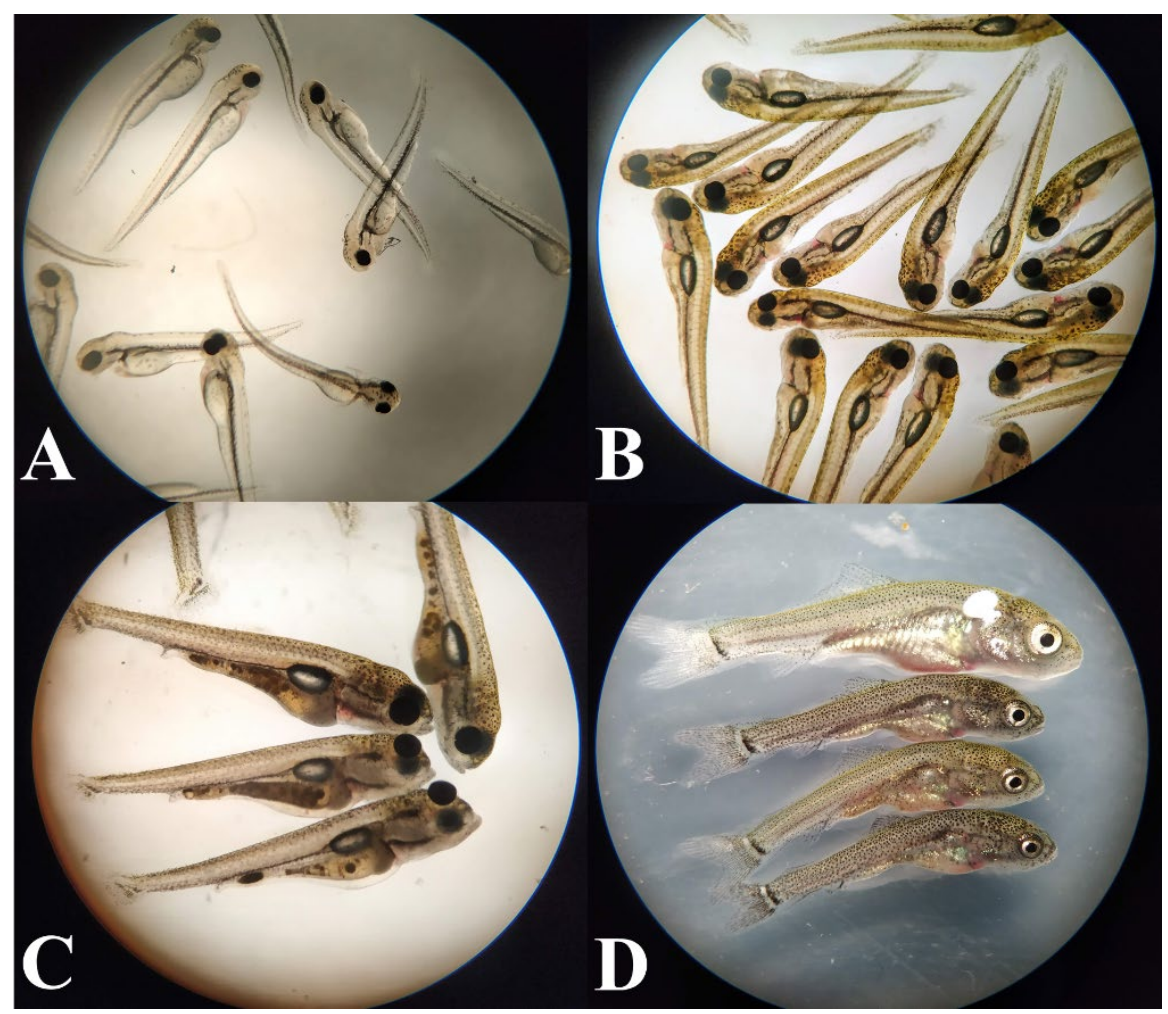

A - free embryo after hatching; B - transition to exogenous nutrition; B - the period of active exogenous nutrition; D - at the end of the experiment

Figure 7. Prelarva and larva of Cyprinus carpio in different periods of the experiment

As a result of rearing the larvae, significant differences from the control were revealed by weight in experimental groups № 2 and № 3 on July 24, 20 (p $\leq$ 0,05), № 4 on July 18, 20, July 24, 20, July 26, $20(\mathrm{p} \leq 0,05)$ (table 7). The total average weights of the larvae of experimental groups № 1, 2, 3 and 4 were more than control by 4,4, 8,1, 14,1 and 19,3\%, respectively. The mean masses were as follows: control - 11,14 mg, experiment № 1 - 11,62 mg, experiment № 2 - 12,04 mg, experiment № 3 - 12,71 mg, experiment № 4 - 13,29 mg.

Table 7. Indicators of mass of Cyprinus carpio larvae

\begin{tabular}{|c|c|c|c|c|c|}
\hline & Control & Experience № 1 & Experience № 2 & Experience № 3 & Experience № 4 \\
\hline Date & & & $\frac{\bar{x} \pm \sigma, \mathrm{M \Gamma}}{C V, \%}$ & & \\
\hline 14.07 .20 & $\frac{1,98 \pm 0,111}{5,6}$ & $\frac{2,06 \pm 0,106}{5,1}$ & $\frac{2,04 \pm 0,118}{5,8}$ & $\frac{2,05 \pm 0,101}{4,9}$ & $\frac{2,05 \pm 0,110}{5,4}$ \\
\hline 16.07 .20 & $\frac{3,04 \pm 0,176}{5,8}$ & $\frac{3,25 \pm 0,186}{5,7}$ & $\frac{3,11 \pm 0,162}{5,2}$ & $\frac{3,12 \pm 0,175}{5,6}$ & $\frac{3,38 \pm 0,214}{6,4}$ \\
\hline 18.07 .20 & $\frac{4,52 \pm 0,277}{6,1}$ & $\frac{5,08 \pm 0,309}{6,1}$ & $\frac{4,80 \pm 0,275}{5,7}$ & $\frac{4,88 \pm 0,256}{5,2}$ & $\frac{5,21^{* *} \pm 0,285}{5,5}$ \\
\hline 20.07 .20 & $\frac{5,85 \pm 0,340}{5,8}$ & $\frac{5,64 \pm 0,309}{5,5}$ & $\frac{5,96 \pm 0,334}{5,6}$ & $\frac{6,36 \pm 0,359}{5,6}$ & $\frac{6,07 \pm 0,347}{5,7}$ \\
\hline
\end{tabular}


Selection and peer-review under responsibility of the Organizing Committee of the conference

eISSN: e-ISSN: 2672-8575

\begin{tabular}{cccccc}
22.07 .20 & $\frac{7,56 \pm 0,421}{5,6}$ & $\frac{7,77 \pm 0,407}{5,2}$ & $\frac{7,86 \pm 0,388}{4,9}$ & $\frac{7,96 \pm 0,435}{5,5}$ & $\underline{8,10 \pm 0,389}$ \\
24.07 .20 & $\frac{8,51 \pm 0,323}{3,8}$ & $\frac{8,99 \pm 0,306}{3,4}$ & $\frac{9,25^{* * *} \pm 0,303}{3,3}$ & $\frac{9,83^{* *} \pm 0,358}{3,6}$ & $\frac{10,11^{* *} \pm 0,341}{3,4}$ \\
26.07 .20 & $\frac{11,14 \pm 0,358}{3,2}$ & $\frac{11,62 \pm 0,277}{2,4}$ & $\frac{12,04 \pm 0,334}{2,8}$ & $\frac{12,71 \pm 0,318}{2,5}$ & $\frac{13,29^{* *} \pm 0,349}{2,6}$ \\
\hline
\end{tabular}

Note - when compared with the control (U-Mann-Whitney test):

$$
*-\mathrm{p} \leq 0,01 ; * *-\mathrm{p} \leq 0,05 \text {. }
$$

Significant differences from the control in length (table 8) began to emerge on the second day of rearing in experimental group № $1(\mathrm{p} \leq 0,05)$. At the end of rearing, the larvae differed from the control in experimental groups 2, 3, and 4. The lengths at the beginning of rearing were $6,40-6,47 \mathrm{~mm}$, at the end from 10,06 to $10,18 \mathrm{~mm}$.

Table 8. Indicators of the length of free embryos and larvae of Cyprinus carpio

\begin{tabular}{|c|c|c|c|c|c|}
\hline Date & Control & Experience № 1 & Experience № 2 & Experience № 3 & Experience № 4 \\
\hline \multicolumn{6}{|c|}{$\underline{\bar{x} \pm \sigma, \mathrm{MM}}$} \\
\hline & & & $C V, \%$ & & \\
\hline \multirow{2}{*}{14.07 .20} & $\underline{6,40 \pm 0,229}$ & $\underline{6,45 \pm 0,238}$ & $\underline{6,45 \pm 0,252}$ & $\underline{6,47 \pm 0,250}$ & $\underline{6,46 \pm 0,247}$ \\
\hline & 3,6 & 3,7 & 3,9 & 3,9 & 3,8 \\
\hline \multirow{2}{*}{16.07 .20} & $\underline{6,91 \pm 0,299}$ & $\underline{6,96^{* * *} \pm 0,465}$ & $\underline{6,97 \pm 0,289}$ & $\underline{6,92 \pm 0,412}$ & $7,00 \pm 0,449$ \\
\hline & 4,3 & 6,7 & 4,1 & 5,9 & 6,4 \\
\hline \multirow{2}{*}{18.07 .20} & $\underline{7,83 \pm 0,382}$ & $\underline{7,89 \pm 0,649}$ & $\underline{7,94^{* * *} \pm 0,479}$ & $\underline{7,97^{* * *} \pm 0,474}$ & $\underline{7,99^{* * *} \pm 0,603}$ \\
\hline & 4,9 & 8,2 & 6,0 & 5,9 & 7,5 \\
\hline \multirow{2}{*}{20.07 .20} & $\underline{8,50 \pm 0,498}$ & $\underline{8,48 \pm 0,376}$ & $\underline{8,63^{*} \pm 0,403}$ & $\underline{8,68^{* *} \pm 0,564}$ & $\underline{8,68 \pm 0,373}$ \\
\hline & 5,9 & 4,4 & 4,7 & 6,5 & 4,3 \\
\hline \multirow{2}{*}{22.07 .20} & $\underline{8,93 \pm 0,578}$ & $\underline{9,04 \pm 0,553}$ & $\underline{9,08 \pm 0,522}$ & $\underline{9,09 \pm 0,545}$ & $\underline{9,14^{* * *} \pm 0,576}$ \\
\hline & 6,5 & 6,1 & 5,8 & 6,0 & 6,3 \\
\hline \multirow{2}{*}{24.07 .20} & $\underline{9,29 \pm 0,651}$ & $\underline{9,49 \pm 0,629}$ & $\underline{9,48^{* *} \pm 0,750}$ & $\underline{9,71^{*} \pm 0,784}$ & $\underline{9,72^{*} \pm 0,842}$ \\
\hline & 7,0 & 6,6 & 7,9 & 8,1 & 8,7 \\
\hline \multirow{2}{*}{26.07 .20} & $\underline{10,06 \pm 0,643}$ & $\underline{10,16 \pm 0,666}$ & $\underline{10,15^{* * *} \pm 0,855}$ & $\underline{10,15^{* *} \pm 1,055}$ & $\underline{10,18^{* *} \pm 1,166}$ \\
\hline & 6,4 & 6,6 & 8,4 & 10,4 & 11,5 \\
\hline & & & $\frac{\frac{M e, \mathrm{MM}}{\min -\max , \mathrm{MM}}}{25 \%-75 \%}$ & & \\
\hline \multirow{4}{*}{14.07 .20} & $\underline{6,32}$ & $\underline{6,41}$ & 6,41 & $\underline{6,45}$ & $\underline{6,50}$ \\
\hline & $\underline{6,14-6,85}$ & $\underline{6,05-6,85}$ & $\underline{5,96-7,12}$ & $\underline{6,05-7,12}$ & $\underline{6,14-6,85}$ \\
\hline & $6,23-6,5$ & $6,23-6,68$ & $6,23-6,68$ & $6,23-6,68$ & $6,23-6,68$ \\
\hline & $\underline{6,85}$ & $\underline{7,03^{* *}}$ & $\underline{7,03}$ & $\underline{7,03}$ & $\underline{7,12}$ \\
\hline \multirow[t]{3}{*}{16.07 .20} & $\underline{6,05-7,65}$ & $\underline{6,05-7,74}$ & $\underline{6,23-7,65}$ & $\underline{6,14-7,65}$ & $\underline{6, \overline{14-7}, 74}$ \\
\hline & $\overline{6,76-7,03}$ & $\overline{6,76-7,12}$ & $6,85-7,12$ & $\overline{6,88-7,12}$ & $6,68-7,3$ \\
\hline & $\underline{7,83}$ & $\underline{8,10}$ & $\underline{8,01^{* *}}$ & $\underline{8,10^{* *}}$ & $\underline{8,10^{* * *}}$ \\
\hline \multirow[t]{3}{*}{ 18.07.20 } & $\underline{6,7 \overline{76-8,72}}$ & $\underline{6, \overline{68-8}}, 99$ & $\underline{6, \overline{94-8,90}}$ & $\underline{7,03-9,08}$ & $\underline{6,85-9,35}$ \\
\hline & $\overline{7,74-8,05}$ & $\overline{7,41-8,37}$ & $\overline{7,77-8,19}$ & $\overline{7,74-8,19}$ & $\overline{7,59-8,37}$ \\
\hline & $\underline{8,54}$ & $\underline{8,46}$ & $\underline{8,63^{*}}$ & $8,86^{* *}$ & 8,54 \\
\hline \multirow[t]{3}{*}{20.07 .20} & $7, \overline{48-9,97}$ & $\underline{7,57-9,43}$ & $\underline{7, \overline{48-9,35}}$ & $7, \overline{57-9,97}$ & $\underline{7,74-9,43}$ \\
\hline & $\overline{8,37-8,63}$ & $\overline{8,46-8,63}$ & $8,54-8,79$ & $8,21-8,97$ & $8,46-8,99$ \\
\hline & $\underline{9,08}$ & $\underline{9,08}$ & $\underline{9,12}$ & $\underline{9,17}$ & $9,26^{* *}$ \\
\hline \multirow[t]{3}{*}{22.07 .20} & $7,57-10,06$ & $7,74-10,06$ & $7,74-9,88$ & $7,74-10,06$ & $7,83-9,97$ \\
\hline & $8,74-9,23$ & $8,74-9,5$ & $\overline{8,81-9,52}$ & $8,81-9,52$ & $\overline{8,99-9,61}$ \\
\hline & 9,43 & 9,52 & $9,61^{* *}$ & $9,97^{*}$ & $10,01^{*}$ \\
\hline \multirow[t]{3}{*}{24.07 .20} & $\underline{7,7 \overline{4-10}, 50}$ & $\underline{7,92-10}, 95$ & $\underline{7,92-11,13}$ & $\underline{7,92-11,13}$ & $\underline{8, \overline{01-11,13}}$ \\
\hline & $\overline{9,26-9,59}$ & $\overline{9,28-9,79}$ & $\overline{9,01-9,97}$ & $\overline{9,5-10,12}$ & $\overline{9,08-10,3}$ \\
\hline & $\underline{10,06}$ & $\underline{10,15}$ & $10,32^{* *}$ & $10,59^{* *}$ & $\underline{10,72^{* *}}$ \\
\hline \multirow[t]{2}{*}{26.07 .20} & $\underline{8,01-11,48}$ & $\underline{8,01-11,66}$ & $\underline{8, \overline{10-11,66}}$ & $\underline{8,01-12,02}$ & $\underline{8, \overline{10-11,93}}$ \\
\hline & $9,9-10,41$ & $9,99-10,5$ & $\overline{9,99-10,68}$ & $\overline{9,41-10,77}$ & $\overline{9,1-11,01}$ \\
\hline
\end{tabular}

Note - when compared with the control (U-Mann-Whitney test):

$*-\mathrm{p} \leq 0,01 ; * *-\mathrm{p} \leq 0,05$. 
Figure 8 shows the indices of medians and percentages of which the differences in the distribution of dimensional characteristics within the groups at the end of the experiment are more clearly visible. In experimental groups 3 and 4, the lengths of the larvae are distributed more dynamically in the interval between 25 and 75 quartiles from 9,41 to $11,01 \mathrm{~mm}$.

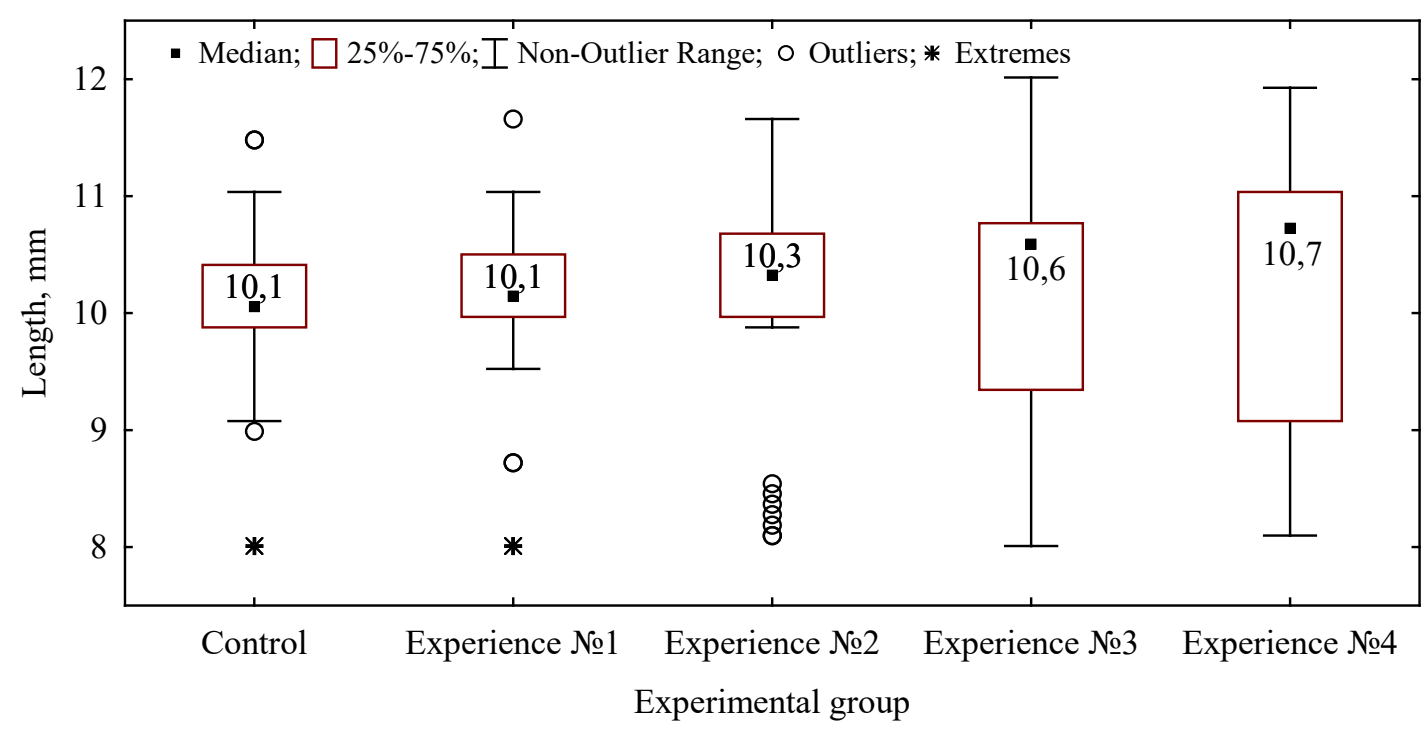

Figure 8. Indicators of the length of Cyprinus carpio larvae at the end of the experiment

According to the data obtained by the construction of variation series (Figure 9), it was found that the maximum number of larvae $72 \%$ in the control group is in the range of lengths 9,5-10,5 mm, the experimental groups are represented by larvae with sizes mainly from 10,0 to $11,0 \mathrm{~mm}$. One can notice a clear predominance of larvae in this size class in experimental groups 3 and 4, which make up 52 and 38 $\%$, respectively. Such a distribution of individuals may indicate pressure by large individuals of the middle class. 

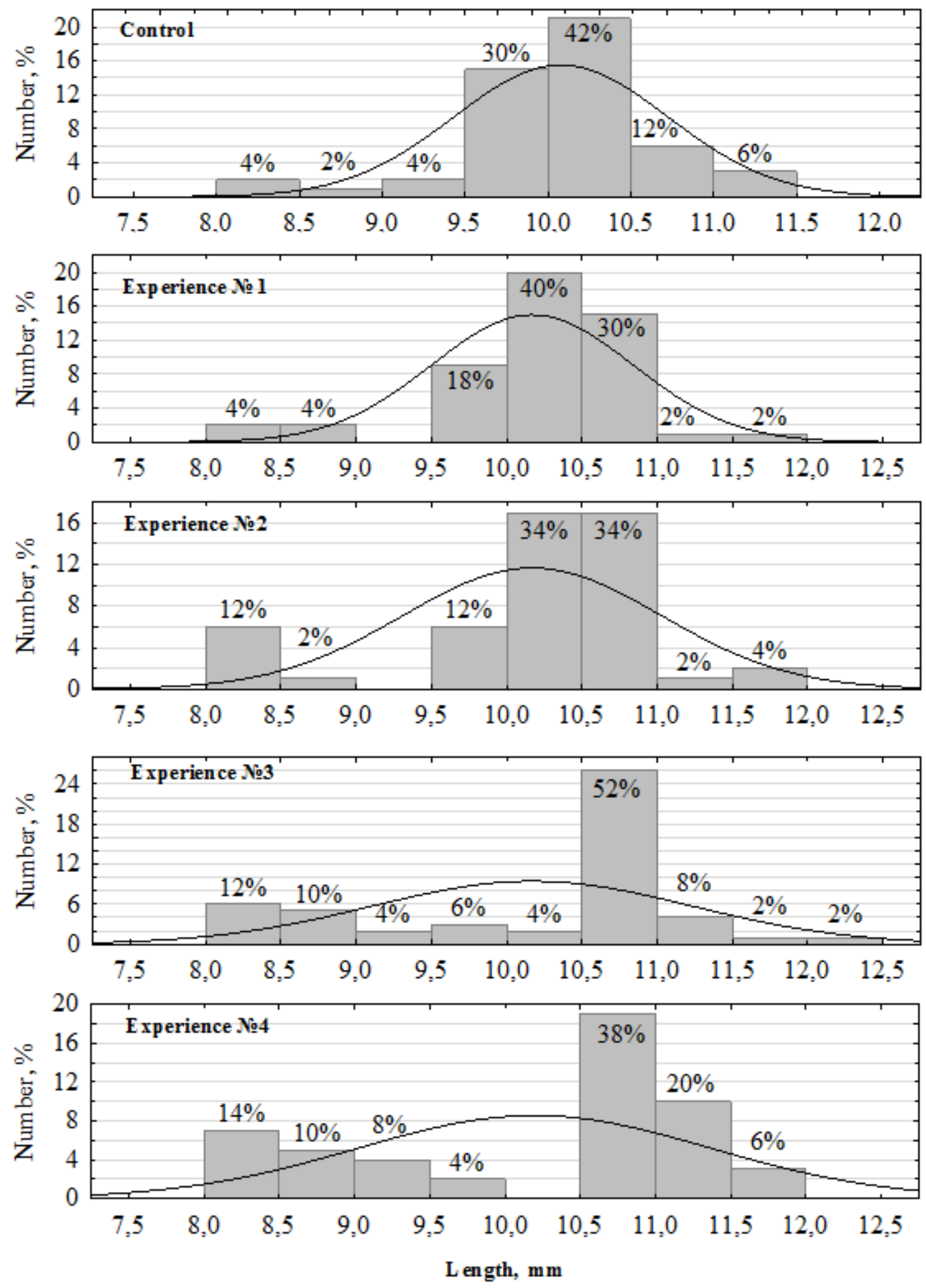

Figure 9. Variation of the length of Cyprinus carpio larvae at the end of the experiment

An important characteristic of the physiological state of the larvae is the indicators of nutritional status. On the diagram (Figure 10), you can see a constant tendency to decrease the values of this indicator throughout the entire duration of the experiment from the control to the experimental group 1,11 to 1,12 units. These values are less than those given by some other researchers (Khabzhokov et al., 2017). 


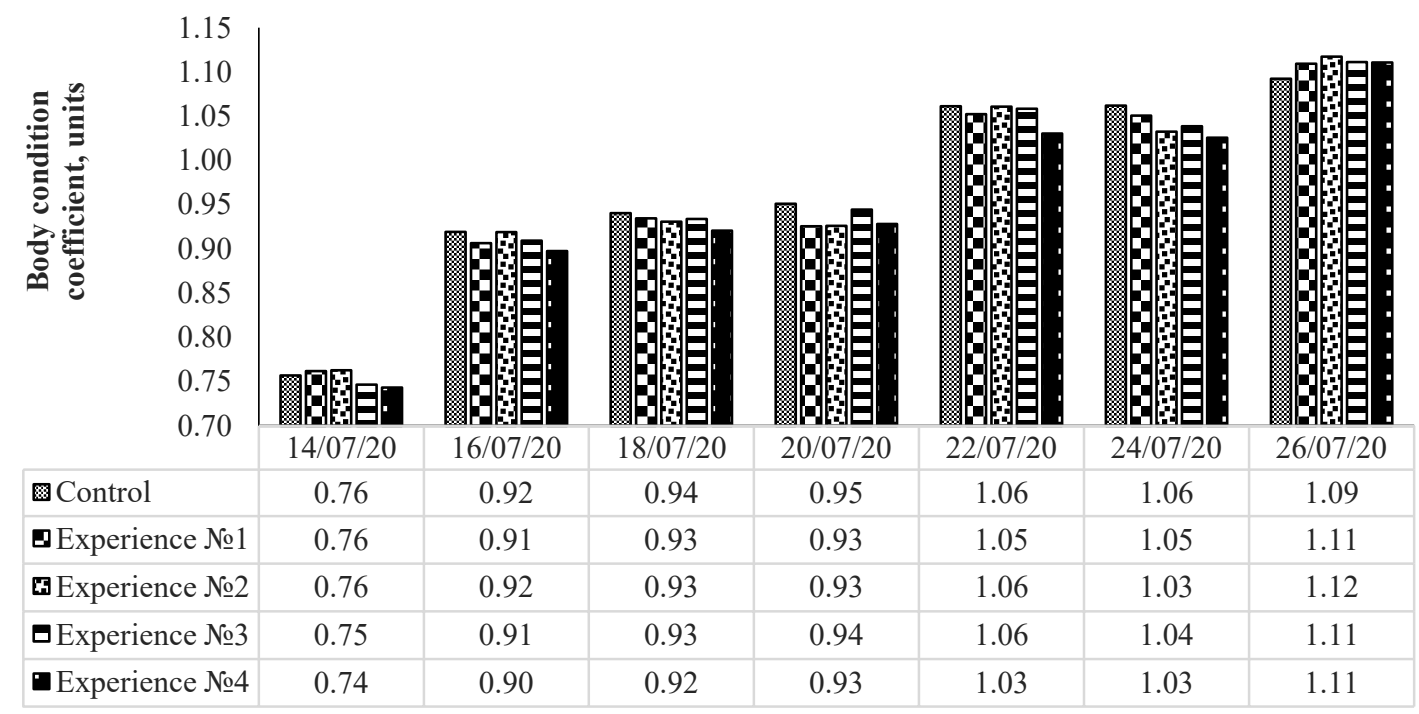

Date

Figure 10. Fulton fatness coefficient of Cyprinus carpio larvae during the experiment

At the beginning of the work, the specific growth rate in all groups was from 21 to $25 \%$ (Figure 11). By the time the larvae were transplanted into the recirculating water trays, this indicator had significantly decreased. Compared with control 12,9\% in experiment № 1 - 5,2 \% or 146,8 \% more, on the other hand in experiment № 3 - 13,2 \%, which is 2,3\% more than it. By the end of the experiment, the values in the groups leveled off in the range from 12,9 to $13,6 \%$.

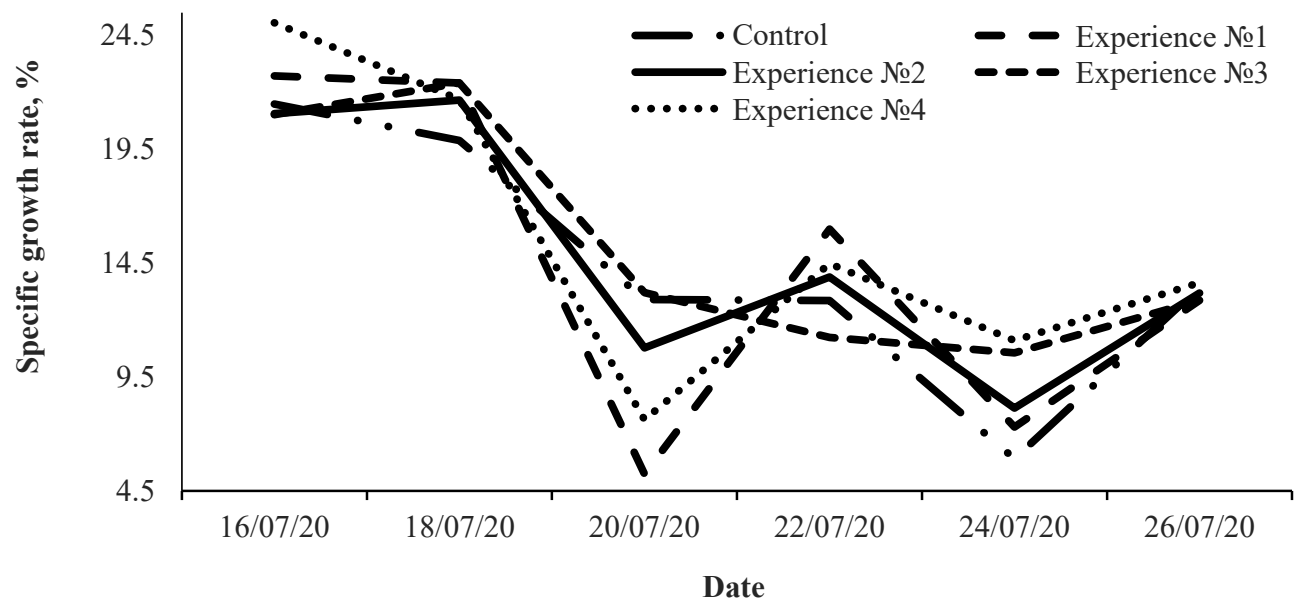

Figure 11. Specific growth rate of Cyprinus carpio larvae during the experiment

In a number of works (Chebotareva et al., 2009; Golovanova et al., 2013; Krylov et al., 2010; Skauli et al., 2000; Vasilieva, 2010) devoted to the study of the effect of EMR on aquatic organisms, various effects were revealed, ranging from early hatching embryos, ending with a decrease in the number of vertebrae in the thoracic spine, which are difficult to correlate with the study, since within the framework of it the water was treated, and not the object itself. 
In one of the works (Pashkov et al., 2013) a significant increase in the number of hatched sterlet prelarvae was revealed in comparison with the control and other variants of the experiment $(10,16,70$ and $90 \mathrm{~Hz}$ ); in our country, water treatment did not affect this indicator, as well as the survival rate in general throughout the experiment. At the same time, on the contrary, an acceleration in the rate of development and an increase in the linear mass characteristics of carp were revealed in comparison with the control when treating water with EMP with a frequency of 100, 500, $1000 \mathrm{~Hz}$. Also, the influence of this factor on the uneven distribution of individuals within the sample was found, mainly from 10,0 to $11,0 \mathrm{~mm}$, which is from 38 to $52 \%$. This is most likely due to the absence in their study of experimental groups with LF EMF more than $90 \mathrm{~Hz}$, in which we found the effects.

The positive effect of LF EMF is most pronounced at the critical stages of fish development, which include the embryonic period. As a result of water treatment with EMF NPs, the basic biochemical and physiological parameters of developing embryos are improved, incl. - their resistance to pathogenic factors (Pashkov et al., 2013).

The nature of the EMR action depends on the oscillation frequency: some resonant frequencies affect more on some aspects of biological activity, others on others. Weak magnetic fields energetically cannot cause the formation of covalent bonds and "large" biological effects of action. To obtain a response, it is necessary to form a kinetic approach to the analysis of such phenomena (Dzhimak, 2009). According to the point of view of Novikov (1998), an approach to the theoretical analysis of the effects of the action of weak magnetic fields on a complex of a large number of ions may turn out to be constructive. Water, especially in aquaculture systems, is saturated with various ions. The system of interacting ions probably leads to the formation of charged polyionic structures - clusters and their interaction with weak fields. These structures can have the property of an electrochemical accumulator that converts the energy of an external electric field, as well as a part of the energy of the environment into the energy of chemical reactions, under the control action of weak components of the field on these processes, ensuring their coherence. A weak magnetic field can perform only a control function, producing a redistribution of the total energy between the components of the solution of the aqueous medium in which the growing objects are located (Dzhimak, 2009).

Previous research work (Shumeyko et al., 2018) with processing water showed the absence of the influence of EMF LF $32 \mathrm{~Hz}$, while revealed an increase in the growth rate of biomass gain by 17,6\% when using $16 \mathrm{~Hz}$ in comparison with the control, a decrease in the number of individuals in smaller size classes. This confirms the theory of the need to select certain (resonant) frequencies that form information signals that control and regulate restorative or adaptive processes in the body.

All figures and tables should be referred in the text and numbered in the order in which they are mentioned.

\section{Conclusion}

It was found that water treatment with EMF NP 50, 100, 500, $1000 \mathrm{~Hz}$ does not affect the incubation time and survival throughout the experiment. As a result of rearing the larvae, significant differences from the control were revealed in terms of weight in the experimental groups with water 
treatment with EMF LF 100, 500, and $1000 \mathrm{~Hz}$. The final average weights of the larvae of the experimental groups were 4,4-19,3\% more than the control.

The obtained results are part of the biotechnology of using water with various modifications in fish farming. Their use has a positive effect on the processes of assimilation of food resources, activation of the energetic apparatus of cells and immunity, an increase in stress resistance and recovery potential of the organism of juveniles of aquaculture objects.

effects of application, research is required to clarify the fundamental, deep principles of this phenomenon and predict the consequences of such interventions.

\section{References}

Aksenov, S. I., Grunina, T. Yu., \& Goryachev, S. N. (2007). O mekhanizmakh stimulyatsii i tormozheniya pri prorastanii semyan pshenitsy $\mathrm{v}$ elektromagnitnom pole sverkhnizkoy chastoty [On the mechanisms of stimulation and inhibition during germination of a wheat family in an ultra-low frequency electromagnetic pole]. Biofizika, 52(2), 332-338. https://doi.org/10.1134/S0006350907020157

Baryshev, M. G., Vasil'ev, N. S., \& Dzhimak, S. S. (2009). Issledovanie vliyaniya magnitoobrabotannoy vody na Saccharomyces cerevisiae [Investigation of the influence of magnetically treated water on the saccharomes]. Vestnik Rossiyskogo universiteta druzhby narodov, 2, 22-25.

Baryshev, M. G., Vasil'ev, N. S., \& Dzhimak, S. S. (2010). O korrelyatsii mezhdu vremenem spinspinovoy relaksatsii magnitoobrabotannoy vody i vyzhivaemost'yu mikroorganizmov [On the correlation between the spin-spin relaxation time of magnetically treated water and the survival of microorganisms]. Ekologicheskiy vestnik nauchnykh tsentrov Chernomorskogo ekonomicheskogo sotrudnichestva , 1, 26-29.

Chebotareva, Yu. V., Izyumov, Yu. G., \& Krylov, V. V. (2009). Vliyanie peremennogo elektromagnitnogo polya na rannee razvitie plotvy Rutilus rutilus (Cyprinidae, Cypriniformes) [Influence of an alternating electromagnetic field on the early development of roach Rutilus rutilus (Cyprinidae, Cypriniformes)]. Vopr. Ikhtiologii, 49(3), 422-428. https://doi.org/10.1134/S0032945209050075

Dzhimak, S. S. (2009). Issledovanie vliyaniya magnitoobrabotannoy vody na biologicheskie ob"ekty [Study of the influence of magnetically treated water on biological objects] [PhD thesis, Kuban State University]. Russian State Library.

Golovanova, I. L., Filippov, A. A., Krylov, V. V., Chebotareva, Yu. V., \& Izyumov, Yu. G. (2013). Deystvie magnitnogo polya i medi na aktivnost' gidroliticheskikh fermentov u segoletok plotvy Rutilus rutilus [Effect of magnetic field and copper on the activity of hydrolytic enzymes in underyearlings of roach Rutilus rutilus]. Voprosy ikhtiologii, 53(2), 227-232. https://doi.org/10.1134/S0032945213020045

Khabzhokov, A. B., Bormotov, G. E., \& Labazanov, A. V. (2017). Vyrashchivanie ryboposadochnogo materiala [Growing fish seed]. Izvestiya KBGAU, 3(17), 52-57.

Kovacheva, N. P., Litvinenko, L. I., Saenko, E. M., Zhigin, A. V., Kryakhova, N. V., \& Semik, A. M. (2019). Sovremennoe sostoyanie i perspektivy razvitiya akvakul'tury artemii v Rossii [Current state and prospects for the development of Artemia aquaculture in Russia]. Trudy VNIRO, 178, 150-171. https://doi.org/10.36038/2307-3497-2019-178-150-171

Krylov, V. V., Chebotareva, Yu. V., Izyumov, Yu. G., \& Osipova, E. A. (2010). Vliyanie magnitnogo polya $\mathrm{i}$ ionov $\mathrm{Cu} 2+$ na rannee razvitie plotvy Rutilus rutilus (L.) (Cyprinidae, Cypriniformes) [Influence of the magnetic field and $\mathrm{Cu} 2+$ ions on the early development of roach Rutilus rutilus (L.) (Cyprinidae, Cypriniformes)]. Zhurn. Sibir. federal. un-ta. Ser. Biologiya, 3(2), 199-210.

Lekhtlaan-Tynisson, N. P., Shaposhnikova, E. B., \& Kholmogorov, V. E. (2004). Deystvie sverkhslabogo polya na kul'tury bakteriy Esherihia coli i Staphylococcus aureus [The action of the superweak 
field on the cultures of bacteria Escherichia salt and Staphylocochus aureus]. Biofizika, 49(3), 519-523.

Novikov, V. V. (1998). Elektromagnitnaya bioinzheneriya [Electromagnetic bioengineering]. Biofizika, 43(4), 588-593.

Novikov, V. V., Sheyman, I. M., Klyubin, A. V., \& Fesenko, E. E. (2007). Vliyanie slabykh i sverkhslabykh kombinirovannykh postoyannogo i peremennogo magnitnykh poley i millimetrovykh voln nizkoy intensivnosti na regeneratsiyu planariy Dugesia tigrina [Influence of weak and superweak combined constant and alternating magnetic fields and low-intensity millimeter waves on the regeneration of planarian Dugesia tigrina]. Biofizika, 52(2), 372-375. https://doi.org/10.1134/S0006350907020200

Novikov, V. V., Sheynman, I. M., \& Fesenko, E. E. (2002). Vliyanie slabykh i sverkhslabykh magnitnykh poley na intensivnost' bespologo razmnozheniya planariy Dugesia tigrina [Influence of weak and superweak magnetic fields on the intensity of asexual reproduction of Dugesya tigrina planaria]. Biofizika, 47(1), 125-129.

Pashinova, N. G., \& Moskul, G. A. (2014). Tovarnoe rybovodstvo: laboratornyy praktikum [Commercial fish farming: laboratory workshop]. Krasnodar.

Pashkov, A. N., Dzhimak, S. S., Melikhova, A. I., Krymov, V. G., Egorov, A. O., \& Baryshev, M. G. (2013). Vliyanie vody, obrabotannoy nizkochastotnym elektromagnitnym polem, na razvitie ikry i rost molodi nekotorykh vidov ryb [Influence of water treated with a low-frequency electromagnetic field on the development of eggs and the growth of juveniles of some fish species]. Ekologicheskiy vestnik nauchnykh tsentrov chernomorskogo ekonomicheskogo sotrudnichestva, 10(4-1), 98-103

Shcherbina, M. A., \& Gamygin, E. A. (2006). Kormlenie ryb v presnovodnoy akvakul'ture [Fish feeding in freshwater aquaculture]. Publisher.

Shchetinkina, M. A., \& Rastopshina, L. V. (2020). Izuchenie vliyaniya nekotorykh faktorov na nachalo inkubatsii ikry karpa [Study of the influence of some factors on the start of incubation of carp eggs]. Agrarnaya nauka - sel'skomu khozyaystvu. Sbornik materialov XV Mezhdunarodnoy nauchno-prakticheskoy konferentsii v 2 kn (pp. 262-264). Barnaul.

Shumeyko, D. V., Abramchuk, A. V., \& Gavrilkin, A. S. (2018). Vliyanie vody podverzhennoy elektromagnitnomu izlucheniyu na molod' afrikanskogo klarievogo soma» [Influence of water exposed to electromagnetic radiation on juvenile African clarius catfish].Vserossiyskaya nauchnoprakticheskaya konferentsiya vodnye bioresursy i akvakul'tura yuga Rossii priurochennaya $k$ 20letiyu otkrytiya v Kubanskom gosudarstvennom universitete napravleniya podgotovki «Vodnye bioresursy i akvakul'tura», 423-429.

Skauli, K. S., Reitan, J. B., \& Walther, B. T. (2000). Hatching in zebrafish (Danio rerio) embryos exposed to a $50 \mathrm{~Hz}$ magnetic field. Bioelectromagnetics, 21(5), 407-410. https://doi.org/10.1002/1521186X(200007)21:5<407::AID-BEM10>3.0.CO;2-V

Temuryants, N. A., \& Grabovskaya, E. Yu. (1992). Reaktsiya krys s raznymi konstitutsional'nymi osobennostyami na deystvie slabykh peremennykh magnitnykh poley krayne nizkikh chastot [The reaction of rats with different constitutional characteristics to the action of weak alternating magnetic fields of extremely low frequencies]. Biofizika, 37(4), 817-823.

Temuryants, N. A., Makeev, V. V., \& Malygina, V. N. (1992). Vliyanie slabykh peremennykh nizkochastotnykh poley na infradiannuyu ritmiku simpatoadrealovoy sistemy krys [Influence of weak variable low-frequency fields on the infra-radial rhythm of the sympathoadreal system of rats]. Biofizika, 37(4), 653.

Vasilieva, E. G. (2010). Vliyanie elektromagnitnykh poley na morfo-biologicheskie parametry gidrobiontov [Influence of electromagnetic fields on morpho-biological parameters of aquatic organisms] [PhD thesis, Astrakhan State Technical University]. Russian State Library.

Voronov, P. M. (1986). Instruktsiya po zagotovke, ochistke, aktivatsii, inkubatsii i kontrolyu za zhiznesposobnost'yu yaits artemii [Instructions for harvesting, cleaning, activation, incubation and control over the viability of brine shrimp eggs]. Krasn. fil. VNIIPRKh. Krasnodar.

Voroshilina, Z. P., Sakovskaya, V. G., \& Khrustalev, E. I. (2005). Tovarnoe rybovodstvo: praktikum. [Commercial fish farming: workshop.] Kaliningrad. 